VARIA

\title{
Merleau-Ponty e a herança hegeliana da dialética
}

\section{Merleau-Ponty and the Heritage of the Hegelian Dialectic}

\author{
*Claudinei Aparecido de Freitas da Silva
}

Para Tarcilio Ciotta, leitor de Hegel

\begin{abstract}
Resumo: Sabe-se que, ao ganhar expressão na obra de Hegel, a dialética ainda terá uma repercussão decisiva no debate contemporâneo. Amostra disso é a sua recepção no seio da tradição fenomenológica inaugurada por Husserl, e que tem, nas figuras de Sartre e de MerleauPonty, duas referências emblemáticas. Meu objetivo, aqui, consiste em fazer um sumário balanço dessa herança conceitual nas mãos desse último autor. Quer dizer: partindo da própria matriz hegeliana, ao situar o seu alcance e os seus limites, trata-se de cortejar a inflexão operada pela noção merleau-pontyana de "hiperdialética", ou seja, uma "dialética sem síntese". O que Merleau-Ponty retrata é o reconhecimento, na dialética, de uma atitude "autocrítica" no sentido de que ela não pode ser nem o "ser para si" nem o "ser em si". Sua dimensão "hiper" acentua, sobremaneira, um movimento de "ir além", de "transcender" toda polaridade rígida, isto é, de desconstruir toda síntese final positiva indiferente ao sentido ambíguo da experiência e da história no coração da contingência.
\end{abstract}

Palavras-chave: Merleau-Ponty. Hegel. Dialética. História. Contingência. Ambiguidade.

\begin{abstract}
As it gained expression in Hegel's work, the dialectic went on to have a decisive repercussion in the contemporary debate. An example is its reception in the phenomenological tradition created by Husserl in the work of Sartre and Merleau-Ponty. My purpose here is to make a summary balance of that conceptual heritage in the hands of the latter author. Starting from the Hegelian matrix, situating its range and its limits, this essay seeks to present the Merleau-Pontyan inflection on the notion of the "hyperdialectical", i.e., "dialectics without synthesis". What Merleau-Ponty portrays is acknowledgment
\end{abstract}

* Colegiado de Graduação e de Pós-Graduação em Filosofia da UNIOESTE - Campus Toledo. <cafsilva@uol.com.br>. 
in the dialectic of a "self-critical" attitude in the sense that it can be neither "being for itself" nor "being itself". Its "hyper" dimension enormously accentuates a move to "go beyond" and "transcend" all rigid polarity, that is, to deconstruct every positive final synthesis indifferent to the ambiguous meaning of experience and history in the heart of contingency.

Keywords: Merleau-Ponty. Hegel. Dialetic. History. Contingency. Ambiguity.

tema da dialética percorre a história da filosofia sob múltiplas vias. Platão e Hegel $^{1}$, para situar ainda Marx, protagonizam tal debate numa inspiração que remonta a Heráclito retraçando, no século XX, novos contornos ou inflexões decisivas. É, pois, imerso nesse último contexto que a figura de Merleau-Ponty entra em cena assumindo uma posição emblemática ao afastar-se quer do bergsonismo ${ }^{2}$, quer, ainda, da própria tradição fenomenológica de que é, diretamente, herdeira. Além disso, é notável o fato de o pensador francês chegar a creditar uma íntima convergência, até então insuspeita, entre a intuição e a dialética numa clara alusão hegeliana. Como ele próprio atesta: "a dialética reencontrada pelos contemporâneos é, como dizia N. Hartmann, uma dialética do real. O Hegel que reabilitaram [...] era o que fazia a dialética emergir da experiência humana [...]. Essa dialética e a intuição não são apenas compatíveis: há um momento em que confluem"3.

Antes de tudo, cabe lembrar, que o tema da dialética é reanimado a partir de um importante registro circunscrito já na primeira metade de século: a releitura de Hegel em curso na França via Kojève e Jean Wahl ${ }^{4}$, sob uma conotação contextualmente existencialista. Merleau-Ponty não só retoma, em grande parte, essa procedência exegética como irá, a

${ }^{1}$ Cf. BENOIT, A. H. R. "A dialética hegeliana como superação da dialética platônica". In: Revista Idéias, IFCH-Unicamp, n. 1, 1995, p. 79-93.

${ }^{2}$ Husserl e Bergson sempre mantiveram certas reservas para com a "dialética" em prol da "intuição" como saber e princípio metodológico (Cf. HUSSERL, E. Ideen, § 24 e BERGSON, H. La pensée et le mouvant, p. 54). Como nota Merleau-Ponty (Signes, p. 196): “Talvez tenhamos mais dificuldade para convencer o leitor de que o século, rumando para a existência, também rumava para a dialética. Blondel, Alain, falaram nela; Croce, naturalmente, também. E, no entanto, Bergson? Husserl? É sobejamente conhecido que buscaram a intuição e que, para eles, a dialética era a filosofia dos raciocinadores, filosofia cega e tagarela ou, como diz J. Beaufret, "ventríloqua'".

3 MERLEAU-PONTY, M. Signes, p. 196; 197. Cf, ainda: MARCEL, G. "Les conditions dialectiques de la philosophie de l'intuition". In: Revue de Métaphysique et de Morale, t. XX, n. 5, 1912, p. 638-652.

${ }^{4}$ Cf. KOJÈVE, A. Introduction à la lecture de Hegel. Paris: Gallimard, 1947; WAHL, J. Le malheur de la conscience dans la philosophie de Hegel. 2. ed. Paris: PUF, 1951. 
rigor, situá-la na confluência de uma compreensão filosófica mais ampla. Tal é a intenção perseguida ao longo de sua reflexão tardia quando passa a redefinir a herança hegeliana da dialética, nos termos de uma "hiperdialética". Assim, para que se possa melhor medir o real alcance dessa formulação programática, um retorno a Hegel se faz minimamente necessário, via a sua própria concepção de dialética.

\section{2}

O ponto de partida de Hegel é a tese de que o real ou o verdadeiro não devem ser interpretados em termos substancialistas. O real não é um ser rígido, maciço, autosubsistente. Este, antes, se revela como "sujeito", "pensamento", "espírito"5. O espírito infinito pode ser descrito como um círculo em que princípio e fim coincidem de modo dinâmico, isto é, como um movimento espiral no qual o particular é sempre posto e abarcado dinamicamente. O espírito é uma unidade-que-se-faz, fundamentalmente, por meio do múltiplo.

Diversamente dos românticos alemães, trata-se de reconhecer que a apreensão da verdade é absolutamente condicionada pela mediação. Não há, sob esse aspecto, um saber imediato. Se, por um lado, o romantismo tem razão quanto à necessidade de ir além dos limites circunscritos do entendimento; por outro, é injustificável apreender o infinito via o sentimento, a intuição ou até mesmo a fé. Tais meios não satisfazem o grau de cientificidade requerido quanto ao conhecimento do absoluto. Um novo método se revela imprescindível a fim de acercar o efetivo em seu dinamismo mais próprio. Esse "método", descreve Hegel, "não é outra coisa que a estrutura do todo, apresentada em sua pura essencialidade" 6 . Pois bem: essa estrutura é a própria "dialética". Hegel corrobora a sua tese: a dialética é o movimento em que "os puros pensamentos se tornam conceitos, e somente então eles são o que são em verdade: automovimentos, círculos. São o que sua substância é: essencialidades espirituais. Esse movimento das essencialidades puras constitui a natureza da cientificidade em geral"7. Nessa direção, se a dialética é a lei suprema do real, qual seria, a rigor, o seu estatuto mais próprio?

5 Cf. HEGEL, G. W. F. Fenomenologia do espírito, §§ 17; 18, p. 34; 35. Conforme esclarece Kesselring trata-se de se objetar a ideia de que a substância seja independente do saber. Por isso, "o programa de Hegel consiste em exprimir a substância como sujeito, isto é, compreender os objetos, aos quais nos aplicamos agindo e conhecendo, a partir dos esquemas sobre os quais nós nos aplicamos aos objetos" (KESSELRING, T. Reconstrução racional da dialética no sentido de Hegel, p. 574).

${ }^{6}$ HEGEL, G. W. F. Fenomenologia do espírito, § 48, p. 53.

${ }^{7}$ HEGEL, G. W. F. Fenomenologia do espírito, §§ 33; 34, p. 45. 
Hegel caracteriza esse estatuto como uma circularidade em ritmo triádico. É o que a Enciclopédia das Ciências Filosóficas descreve ao retratar os três momentos constituintes da dialética: "a) o lado abstrato ou do entendimento; b) o dialético ou negativamente-racional; c) o especulativo ou positivamente racional"8. Inicialmente, adverte o filósofo: "esses três lados não constituem três partes da Lógica, mas são momentos de todo [e qualquer] lógico-real, isto é, de todo conceito ou de todo verdadeiro em geral" 9 . Comecemos, pois, pela primeira forma do lógico, aquela que, segundo Hegel, constitui um momento essencial da cultura: o entendimento. Trata-se do momento abstrato, ou seja, a atividade que abstrai conceitos determinados e se detém nessa de-terminação própria do finito. A esse modo:

A atividade do entendimento em geral consiste em conferir a seu conteúdo a forma da universalidade; e, na verdade, o universal posto por meio do entendimento é algo abstratamente universal, que como tal é sustentado em contraposição ao particular, mas, por isso também, de novo determinado ao mesmo tempo como particular, ele mesmo. Enquanto o entendimento se refere a seus objetos, separando e abstraindo, ele é o contrário da intuição e sensação imediata, que como tal só lida exclusivamente com o concreto e nele permanece ${ }^{10}$.

Hegel não subestima o alcance dessa potência abstrativa em todas as esferas da cultura. Da arte, passando pela religião e pelo direito até chegar à filosofia, não se pode prescindir do entendimento como um princípio que torna o pensamento preciso para além do vago e do indeterminado. Por outro lado, é de se levar em conta que, ao se destacar e se afastar do particular, para, enfim, se elevar ao universal, o entendimento não constitui um âmbito último. O entendimento é finito de maneira que se torna premente avançar para além dele já que encerra um conhecimento ainda inadequado, ou seja, um domínio de abstração demarcando oposições intransponíveis. Ora, é preciso transcender os limites da abstração rigidamente intelectual, já que o próprio entendimento se converte, como diz Hegel, em seu contrário.

É agora que a Lógica reconhece seu segundo momento, quer dizer, o dialético ${ }^{11}$ ou negativamente-racional como impulso que transpõe a

\footnotetext{
${ }^{8}$ HEGEL, G. W. F. Enciclopédia (I), §79, p. 159. São esses três momentos que, habitualmente, se conceituam enquanto "tese", "antítese" e "síntese", respectivamente.

${ }^{9}$ HEGEL, G. W. F. Enciclopédia (I), §79, p. 159.

${ }^{10}$ HEGEL, G. W. F. Enciclopédia (I), §80, p.159-160.

${ }^{11}$ Stanguennec mostra que, embora Hegel não designe a dialética como "o método especulativo" (especialmente, na Enciclopédia §§237-244), é o segundo dentre os três momentos do método (começo, progressão e fim), que a dialética é caracterizada, ou seja, como "o negativo do começo". Assim: "o momento negativo é chamado o momento dialético porque é ele que
} 
rigidez do entendimento. Hegel descreve essa passagem nos seguintes termos:

O momento dialético é o próprio suprassumir-se de tais determinações finitas e seu ultrapassar para suas opostas [...]. A dialética é esse ultrapassar imanente, em que a unilateralidade, a limitação das determinações do entendimento é exposta como ela é, isto é, como sua negação. Todo finito é isto; suprassumir-se a si mesmo. O dialético constitui, pois a alma motriz do progredir científico; e é o único princípio pelo qual entram no conteúdo da ciência a conexão e a necessidade imanente; assim como, no dialético em geral, reside a verdadeira elevação - não exterior - sobre o finito ${ }^{12}$.

O que Hegel dita é a tese de que essa definição do dialético não se confunde com uma arte exterior ou com uma simples aparência de contradições entre conceitos determinados. O dialético não se explica segundo um sistema subjetivo de balanço: ele não é um raciocínio que ora se dirige para um lado, ora para outro, validando, à maneira sofística, determinações unilaterais e abstratas. Por isso,

É da mais alta importância apreender e conhecer devidamente o dialético. O dialético, em geral, é o princípio de todo o movimento, de toda a vida, e de toda a atividade na efetividade. Igualmente, o dialético é também a alma de todo o conhecer verdadeiramente científico ${ }^{13}$.

Hegel diz mais: esse momento não é constitutivo apenas do entendimento, mas também do efetivo, da experiência:

Por mais que o entendimento costume opor resistência à dialética, ela não pode, de modo algum, ser considerada como presente simplesmente para a consciência filosófica; mas, antes, aquilo de que se trata aqui, já que se encontra também em qualquer outra consciência, e na experiência universal. Tudo o que nos rodeia pode ser considerado como um exemplo do dialético ${ }^{14}$.

Ao caracterizar a natureza do dialético, Hegel chama a devida atenção para o fato de que o princípio desigual na consciência entre o Eu e a

permite realizar o "passo" ou a "travessia" para outro conceito. Nessa marcha é que a dialética é entendida como método. Dos três momentos do movimento, ele é o único digno de carregar o nome da totalidade deste movimento. O momento do negativo confere-se esta dignidade em virtude do poder da dedução [...]. O dialético enquanto momento metodológico da progressão realiza, pois, diversamente a dialética. Em síntese, a elucidação das relações entre o dialético e a dialética em Hegel, conduz à ideia de que não há uma dialética, mas as dialéticas" (STANGUENNEC, A. O dialético, a dialética, as dialéticas em Hegel, p. 36; 38).

${ }^{12}$ HEGEL, G. W. F. Enciclopédia (I), § 81, p. 162; 163.

${ }^{13}$ HEGEL, G. W. F. Enciclopédia (I), § 81, p. 163.

${ }^{14}$ HEGEL, G. W. F. Enciclopédia (I), § 81, p. 164-165. 
substância pode parecer uma "falha", mas, no fundo, nada mais é que a sua própria alma. O negativo é justo aquilo que os move. Eis a razão pela qual a Fenomenologia do Espírito se reporta à "força portentosa do negativo, energia do pensar, do puro $\mathrm{Eu}^{15}$ levando luz à série de contradições e de oposições que caracterizam o finito. É sustentando esse argumento que Hegel já assinala o quanto a experiência é um campo conceitual decisivo inscrito ao próprio movimento dialético. O negativo é o "processo que conduz através do sistema da experiência à ciência do verdadeiro que está na forma do verdadeiro" ${ }^{16}$. De fato, Hegel compreende que qualquer coisa que exista ou aconteça não está fora do absoluto como um momento absolutamente não suprimível dele. A filosofia se encontra num novo começo da cultura, na medida em que ela exprime, por assim dizer, "a vida plena que se adentra na experiência; momento em que o rigor do conceito penetra a profundeza da Coisa" ${ }^{17}$. Isso explica porque o movimento do conceito não se apoia em proposições mortas e rígidas. Ele não é um "saber carente-de-vida" ${ }^{18}$, uma vez que não se reduz num monótono formalismo ${ }^{19}$. É em tal contexto que o negativo exerce um papel decisivo: "a negatividade é, nesse movimento, o diferenciar e o pôr do ser-aí; e é, nesse retornar a si, o vir-a-ser da simplicidade determinada" 20. Hegel não toma o devir como um momento qualquer, mas como o momento genuinamente dialético que leva o espírito ao positivo. A vida do espírito não é aquela que se esquiva da morte, mas, ao contrário, aquilo que a suporta e nela se mantém. Nesse processo, o negativo é a mola que impele a razão mesma a uma síntese superior.

O que Hegel mostra é que a "síntese" aqui efetivada exprime o quanto a filosofia não permanece num resultado puramente negativo da dialética. Daí a terceira forma do lógico à qual se chega, ou seja, o momento especulativo ou positivamente-racional. Este "apreende a unidade das determinações em sua oposição: o afirmativo que está contido em sua resolução e em sua passagem [a outra coisa]" ${ }^{21}$. Do especulativo se depreendem três aspectos:

\footnotetext{
${ }^{15}$ HEGEL, G. W. F. Fenomenologia do espírito, § 32, p. 44.

${ }^{16}$ HEGEL, G. W. F. Fenomenologia do espírito, § 38, p. 47.

${ }^{17}$ HEGEL, G. W. F. Fenomenologia do espírito, § 4, p. 27.

${ }^{18}$ HEGEL, G. W. F. Fenomenologia do espírito, § 52, p. 57.

19 "É, pois, inútil" - nota Hegel - "aplicar de fora o formalismo ao conteúdo do concreto; [pois] esse conteúdo é nele mesmo o passar ao formalismo. Mas [então] o formalismo deixa de ser formalismo, porque a forma é o vir-a-ser inato do próprio conteúdo do concreto" (HEGEL, G. W. F. Fenomenologia do espírito, § 56, p. 60). O fato é que, "no pensar conceitual, o negativo pertence ao conteúdo mesmo" (Idem, Op. cit., § 59, p. 62).

${ }^{20}$ HEGEL, G. W. F. Fenomenologia do espírito, § 53, p. 57. "A negatividade é o ponto simples da relação negativa consigo, a fonte mais íntima de toda a atividade, do automovimento vivo e espiritual" (Idem, Wissenschaft der Logik (II), p. 563).

${ }^{21}$ HEGEL, G. W. F. Enciclopédia (I), § 82, p. 166.
} 
1) A dialética tem um resultado positivo por ter um conteúdo determinado, ou por seu resultado na verdade não ser o nada vazio, abstrato, mas a negação de certas determinações que são contidas no resultado, precisamente porque este não é um nada imediato, mas um resultado; 2) Esse racional, portanto, embora seja algo pensado - também abstrato -, é ao mesmo tempo algo concreto, porque não é unidade simples, formal, mas unidade de determinações diferentes. Por isso a filosofia em geral nada tem a ver, absolutamente, com simples abstrações ou pensamentos formais, mas somente com pensamentos concretos; 3) $\mathrm{Na}$ Lógica especulativa, a simples Lógica de entendimento está contida e pode ser construída a partir dela; para isso não é preciso senão deixar de lado o dialético e racional ${ }^{22}$.

O especulativo capta, dentro de si, o positivo emergente da síntese dos opostos. Este é, conforme metaforiza a Fenomenologia do Espírito, o momento do "delírio báquico": "O verdadeiro é assim o delírio báquico, onde não há membro que não esteja ébrio; e porque cada membro, ao separar-se, também imediatamente se dissolve, esse delírio é ao mesmo tempo repouso translúcido e simples" ${ }^{23}$. Ora, o fato notado por Hegel é o de que a tradição filosófica só teria incorporado os dois primeiros momentos, deixando de identificar mais, especificamente, esse terceiro: o "especulativo". Momento em que se processa a reafirmação do positivo mediante a negação do negativo próprio das antíteses dialéticas e, portanto, como elevação do positivo das teses a um plano mais elevado. $\mathrm{O}$ que se desvela, nesse terceiro estágio, é o princípio de uma "superação" (Aufhebung), ou melhor, uma "eliminação-conservação" dos momentos precedentes. Ao mesmo tempo, essa última ambivalência não é casual. Hegel a toma no sentido negativo/positivo comumente evocado pela expressão alemã Aufhebung para exprimir a dimensão do absoluto como ponto culminante da razão. Para ele, com efeito, a negação especulativa não é uma aniquilação total, nem uma reserva definitiva, mas é propriamente uma conservação daquilo que é negado e, como se acaba de mostrar, uma elevação a um nível superior. Enquanto a proposição da velha lógica permanecera fechada nos limites rígidos do entendimento, a proposição especulativa é estruturalmente bem mais dinâmica segundo a realidade por ela expressa. A dialética se torna a expressão desse devir em que o absoluto é a realidade suprema, quer dizer, a origem do real. Esse devir ainda não é sem fim, pois, como diz Hegel,

\footnotetext{
${ }^{22}$ HEGEL, G. W. F. Enciclopédia (I), § 82, p. 166-167.

${ }^{23}$ HEGEL, G. W. F. Fenomenologia do espírito, § 47, p.53.
} 
[...] o elemento ou conteúdo da filosofia não é o abstrato e o inefetivo, mas sim o efetivo, que se põe a si mesmo e é em si vivente: o ser-aí em seu conceito. É o processo que produz e percorre os seus momentos; de modo que o movimento total constitui o positivo e sua verdade. Movimento esse que também encerra em si o negativo ${ }^{24}$.

Hegel acrescenta que cada momento do efetivo se revela como indispensável do absoluto, ou seja, este se faz e se realiza em cada um e em todos aqueles momentos de modo necessário. Que se tome, a título ilustrativo, o desenvolvimento de uma planta. Há o processo de germinação em que o botão é a de-terminação, isto é, negação. Ora, tal de-terminação é extraída e, portanto, superada pelo florescimento o qual, por sua vez, nega essa determinação. A flor nada mais é do que a manifestação da positividade do botão. E, assim, sucessivamente, a flor é de-terminação que implica uma nova negatividade que será ainda superada pelo fruto. Nesse processo, todo momento se torna essencial ao outro e a vida da planta pouco a pouco nada mais é do que esse movimento que põe os vários momentos num ato de superação contínua. $\mathrm{O}$ que Hegel percebe é que o efetivo é um processo que autocria à medida que percorre seus momentos sucessivos; processo no qual o positivo é o próprio movimento de um auto-enriquecimento progressivo (da planta ao botão, do botão à flor, da flor ao fruto) ${ }^{25}$. Aqui, ganha especial relevo a circularidade mesma do espírito (o absoluto) como um "círculo de círculos" ${ }^{26}$, quer dizer, como um refletir-se em si mesmo instituinte em três momentos essenciais: o do ser "em si"; o do "ser outro" ou "fora de si" e o do "retorno a si" ou o "ser em si e para si".

Com isso, o conceito de experiência retorna à cena. Hegel observa: "esse movimento dialético que a consciência exercita em si mesma, tanto em seu saber como em seu objeto, enquanto dele surge o novo objeto verdadeiro para a consciência, é justamente o que se chama experiência" ${ }^{27}$. Nessa perspectiva,

\footnotetext{
${ }^{24}$ HEGEL, G. W. F. Fenomenologia do espírito, § 47, p. 53. Essa relação intrínseca entre o conceitual e o concreto é aferida pela célebre máxima: "o que é racional, isto é efetivo; e o que é efetivo, isto é racional" (Idem, Filosofia do direito, p. 41).

${ }^{25}$ Cf. HEGEL, G. W. F. Fenomenologia do espírito, § 2, p. 26.

${ }^{26}$ Assim, se é verdade que o círculo do absoluto marca seu ritmo, via esse três momentos constitutivos (o em-si, o fora-de-si e o retorno-a-si), é porque cada um deles exprime respectivamente a ideia, a natureza e o espírito. Essa é a razão pela qual Hegel caracterizará a sua filosofia em três âmbitos distintos de tratamento: a Lógica, a Filosofia da Natureza e a Filosofia do Espírito.

${ }^{27}$ HEGEL, G. W. F. Fenomenologia do espírito, § 86, p. 80. "A consciência nada sabe, nada concebe, que não esteja em sua experiência [...]. Experiência é justamente o nome desse movimento em que o imediato, o não-experimentado, ou seja, o abstrato - quer do ser sensível, quer do Simples apenas pensado - se aliena e depois retorna a si dessa alienação; e por isso - como é também propriedade da consciência - somente então é exposto em sua efetividade e verdade" (Idem, Op. cit., § 36, p. 46).
} 
A experiência (Erfahrung) que a consciência faz sobre si mesma não pode abranger nela, segundo seu conceito, nada menos que o sistema completo da consciência ou o reino total da verdade do espírito. Seus momentos se apresentam assim nessa determinidade peculiar, de não serem momentos abstratos ou puros, mas, sim, tais como são para a consciência ou como a mesma aparece em sua relação para com eles; por isso os momentos do todo são figuras da consciência ${ }^{28}$.

A experiência é o pano de fundo pelo qual, dialeticamente, o espírito ou a consciência erige sua verdade e seu sistema. Ela é, como descreve Taggart, o que imprime, em meio ao movimento dialético, resistência a qualquer crítica cética ${ }^{29}$. Os dados da experiência estão longe de serem deduzidos a partir da necessidade do pensamento puro, uma vez que

O pensamento não é efeito dos dados sensíveis, necessários a sua manifestação: eles lhes coexistem necessariamente numa unidade mais elevada [...]. Em síntese, a dialética é um movimento do pensamento puro, mas possível apenas na presença de uma matéria da intuição. $\mathrm{O}$ pensamento, tal qual nós o conhecemos, é essencialmente mediado, requer, para se exercer, um dado imediato, e é na sensação, plano de fundo necessário de todo o processo dialético que nos deveremos, enquanto nossa ciência atual está em questão, procurar este elemento imediato $^{30}$.

Posto isso, a consciência está sempre envolta numa experiência, a experiência de si mesma e do seu objeto. É sob tal condição que a dialética é o movimento total do conceito e, a fenomenologia, a ciência da experiência da consciência como uma forma histórica de "figuras" na qual a consciência realiza a mediação entre si mesma e o seu mundo. A célebre parábola do senhor e do servo posta em jogo na "dialética do reconhecimento" se torna, paradigmaticamente, uma dessas figuras que ilustram o quanto a consciência-de-si é, eo ipso, uma consciência indivisa. Esta se manifesta como uma consciência duplicada: é "o intuir de uma consciência-de-si numa outra" 31 . Hegel, enfim, realoca uma posição do

\footnotetext{
${ }^{28}$ HEGEL, G. W. F. Fenomenologia do espírito, § 89, p. 81.

29 “Toda proposição versando sobre a existência deve ser fundada diretamente sobre a experiência imediata da realidade ou vinculada por uma cadeia de juízos mediados a uma proposição deste gênero. A diferença que separa o mundo real e o mundo ideal é uma diferença que o pensamento não pode aniquilar, porque para o puro pensamento ela não existe" (TAGGART, J. E. M. Do verdadeiro sentido da dialética de Hegel, p. 328).

${ }^{30}$ TAGGART, J. E. M. Do verdadeiro sentido da dialética de Hegel, p. 317.

${ }^{31}$ HEGEL, G. W. F. Fenomenologia do espírito, § 207, p. 159. Cf. BAVARESCO, A. \& COSTA, A. O. "Movimento lógico da figura hegeliana do senhor e do servo". In: Trans/Form/Ação, Marília, v. 36, n. 1, jan.-abr. 2013, p. 37-60.
} 
homem como negatividade criadora e não como essência ${ }^{32}$ fixa e estática, abrindo, dessa maneira, outro horizonte possível da Razão.

Aos olhos de Merleau-Ponty, a Fenomenologia do Espírito é uma "filosofia militante, não ainda triunfante [...]. Ela visa, antes, uma reconciliação do homem com o homem [...] jamais buscando fazer entrar a história total nos quadros de uma lógica preestabelecida" ${ }^{33}$. Sob esse prisma, Hegel se projeta como uma figura seminalmente decisiva ao refutar duas concepções arbitrárias, ao mesmo tempo, parciais e abstratas: de um lado, a do determinismo, em que o acontecimento é uma cadeia de causas necessárias e, de outro, a do providencialismo leibniziano, que encerra a história mediante o desígnio de uma onipotência divina. É levando em conta esse duplo combate, comenta Lebrun, que Merleau-Ponty defenderá Hegel da acusação de "realismo histórico", à medida que o Conceito hegeliano unifica, purificando as noções de "necessidade" e de "providência" ${ }^{34}$. Há, pois, um equívoco comumente atribuído a Hegel de conceber a história como "um ídolo externo" a ser incondicionalmente venerado. Ora, "providência" e "necessidade" não passam de "abstrações gêmeas que Hegel não aceita. O que objetiva nota Merleau-Ponty - é o momento em que o interior se faz exterior, a reviravolta ou a transferência pela qual passamos para o outro e para o mundo como o mundo e o outro para nós: numa palavra, a ação"35. É que Hegel busca tomar o Espírito ou a Unidade como um porvir e um problema, emergindo na experiência, em vez de supô-los dados. Em tal perspectiva, Hegel

[...] está na origem de tudo o que se realizou de grande na filosofia há um século, por exemplo, do marxismo, de Nietzsche, da fenomenologia, do existencialismo alemão e da psicanálise. Ele (Hegel) inaugura a tentativa de explorar o irracional e integrá-lo em uma razão alargada que permanece a tarefa de nosso século. Ele é o inventor desta Razão mais compreensiva em que o entendimento torna-se capaz de respeitar a variedade e a singularidade dos psiquismos, das civilizações, dos métodos de pensamento e a contingência da história, não renunciando, no entanto, a dominá-los a fim de conduzi-los à sua própria verdade ${ }^{36}$.

\footnotetext{
${ }^{32} \mathrm{Hegel}$ redefine, nesse contexto, a noção de essência como sendo "a mutabilidade e transitoriedade do finito tomado em toda a variedade da existência mais própria" (HEGEL, G. W. F. Nürnberger und Heidelberger Schriften (1808-1817), § 43/75, p. 96).

${ }^{33}$ MERLEAU-PONTY, M. Sens et non-sens, p. 81.

${ }^{34}$ LEBRUN, G. O avesso da dialética, p. 37-38.

${ }^{35}$ MERLEAU-PONTY, M. Signes, p. 90.

${ }^{36}$ MERLEAU-PONTY, M. Sens et non-sens, p. 79.
} 
O que Merleau-Ponty restitui nessa herança é a tarefa de explorar outra ideia de razão não mais indiferente à história e à experiência. A obra de Hegel se torna, desde então, um pensamento de vanguarda quanto à compreensão dos problemas seculares, sejam eles filosóficos, políticos ou religiosos:

Pode se falar de um existencialismo de Hegel, no sentido em que ele não se propõe encadear conceitos, mas revelar a lógica imanente da experiência humana em todos os seus setores [...]. Além disso, o homem não é de uma só vez, uma consciência possuída na claridade de seus próprios pensamentos, mas uma vida dada a si-própria, que busca se compreender a si mesma. Toda a Fenomenologia do Espírito descreve esse esforço que faz o homem para se reapropriar ${ }^{37}$.

Mais que isso: o elogio a Hegel vai à contramão de Kant:

Aqui a experiência não é mais unicamente como em Kant, nosso contato todo contemplativo com o mundo sensível. Ora, a palavra retoma a ressonância trágica que possui na linguagem comum quando um homem fala acerca do que ele tem vivido. Essa não é mais a experiência de laboratório, é a experimentada da vida ${ }^{38}$.

Merleau-Ponty vê emergir, em franca oposição a Kant, uma dimensão "trágica" que a obra de Hegel transfiguraria. Mais que uma postura puramente contemplativa, tal obra não abstém de interrogar a experiência. Ela projeta Hegel como um autor "romântico", hostil à abstração do conceito, e, em tal medida, como um pensador trágico, aquele "'do trabalho, da dor e da paciência do negativo'" 39. Ora, esse Hegel aqui redescoberto, anti-kantiano por definição, é o que confere outro estatuto à condição humana, abrindo o campo de "nossa existência indivisa"40; razão pela qual, "pela primeira vez desde Hegel, a filosofia militante não

\footnotetext{
${ }^{37}$ MERLEAU-PONTY, M. Sens et non-sens, p. 81; 82. Esse "existencialismo hegeliano" aqui cunhado por Merleau-Ponty remonta, muito provavelmente, à atmosfera da recepção de Hegel em solo francês. Nessa retrospectiva, Hyppolite rememora a querela marxista corrente, entre os anos de 1940 e 1950, de que "os existencialistas deviam sair de sua liberdade sem raiz e sem história. Eles deviam reconciliar o para-si com a história, reintroduzir a continuidade e a determinação da história. Ora, a Fenomenologia da Percepção, de Merleau-Ponty, se orientava nessa via que era também aquela de Hegel" (HYPPOLITE, J. Figures de la pensée philosophique, p. 236-237).

${ }^{38}$ MERLEAU-PONTY, M. Sens et non-sens, p. 82. Conforme Lima Vaz, "Hegel, em suma, traduz em necessidade dialética a necessidade analítica com que Kant unifica as categorias do Entendimento na unidade transcendental da apercepção, no Eu penso" (VAZ, H. C. L. "Senhor e escravo: uma parábola da filosofia ocidental", p. 15).

${ }^{39}$ HYPPOLITE, J. Figures de la pensée philosophique, p. 233.

${ }^{40}$ MERLEAU-PONTY, M. Parcours deux (1951-1961), p. 41.
} 
reflete sobre a subjetividade, mas sobre a intersubjetividade" ${ }^{41}$. Mais: "Hegel condena uma solução niilista que concluiria, por causa disso, à vaidade de si e dos outros" 42 .

Por outro lado, é também verdade que essa não é a única imagem de Hegel. Conforme retrata Hyppolite, não se pode esquecer o Hegel ainda ortodoxo, um "fabricante de sistema", o sistema da síntese e da reconciliação. Isso tudo porque, malgrado ter conquistado o mérito de abrir uma nova ideia de razão num contexto mais abrangente da experiência, coexistem, em Hegel - demarca Merleau-Ponty - dois limites incontornáveis. Um primeiro deles é o fato de que a teoria do Estado e a teoria da guerra parecem reservar ao saber absoluto do filósofo: "Hegel é o único a pensar que seu sistema contém a verdade de todos os outros e, quem não os conhecesse através de sua síntese não os conheceria de modo algum" 43 . O que se postula, nesse modelo reflexivo, é o ideal de uma "marcha do espírito" como essência e motor da história, em que os instantes particulares (resultantes de paixões contingentes e superficiais) são superados pela unidade universal do espírito. Os indivíduos se tornam, pois, "instrumentos inconscientes" dessa atividade interior como desenvolvimento necessário da razão na história ${ }^{44}$. Tratase de uma razão que "busca a verdade de todas as outras existências, integrando-as, ultrapassando-as e, do fundo de sua sabedoria, obtendo a revelação do sentido da história que os demais homens se limitariam a suportar"45.

Em Éloge de la Philosophie, Merleau-Ponty se reporta a certo desespero que invade a filosofia em duas direções: existem aqueles

[...] que vêem na história um destino exterior de cujo proveito o filósofo é convidado a suprimir-se como filósofo; outros mantêm a autonomia filosófica apenas na medida em que separam a filosofia da circunstância e fazem dela um álibi honorífico. Defende-se a filosofia e defende-se a história como tradições rivais ${ }^{46}$.

\footnotetext{
${ }^{41}$ MERLEAU-PONTY, M. Sens et non-sens, p. 163.

${ }^{42}$ MERLEAU-PONTY, M. Notes de cours (1959-1961), p. 287.

${ }^{43}$ MERLEAU-PONTY, M. Signes, p. 102.

${ }^{44}$ HEGEL, G. W. F. Filosofia do direito, § 344, p. 307. Trata-se de renunciar a uma concepção de Estado à maneira de um sistema que reserva, para alguns, o papel de "sujeitos da história" enquanto que os outros permanecem "objetos" diante dessa vontade transcendente. Ora, o que Merleau-Ponty visa desmistificar é uma suposta ilusão messiânica, típica em todo humanismo formal (abstrato) que arbitra a exigência de um Espírito Mundial em que a universalidade só é concebida, mas não vivida. Tudo se passa como se "não houvesse a contingência ou como se a ambiguidade das ocasiões, a astúcia e a violência estivessem eliminadas da história" (MERLEAU-PONTY, M. Humanisme et terreur, p. 111).

${ }^{45}$ MERLEAU-PONTY, M. Sens et non-sens, p. 162.

${ }^{46}$ MERLEAU-PONTY, M. Éloge de la philosophie, p. 50.
} 


\section{Ora, é certo que Hegel já as havia identificado}

[...] fazendo da filosofia a intelecção da experiência histórica e da história o devir da filosofia; no entanto, o conflito estava apenas mascarado: a filosofia permanece para Hegel, saber absoluto, sistema, totalidade. A história de que fala o filósofo não é seriamente história, isto é, seja lá o que for que façamos, a história é universal, está compreendida, cumprida, morta. Inversamente, porém, a história, enquanto puro fato ou acontecimento introduz no sistema a que é incorporada, um movimento interior que o dilacera [...]. A história universal de Hegel é o sonho da história. Como nos sonhos, tudo o que é pensado é real, tudo o que é real é pensado ${ }^{47}$.

O segundo limite do sistema hegeliano é simultâneo ao primeiro, aqui inscrito. Trata-se do momento lógico da síntese como princípio da dialética. A questão é que a

[...] síntese não contém, efetivamente, todos os pensamentos passados, que não é tudo o que eles foram, enfim, que nunca é síntese em e para si, ao mesmo tempo. Ou seja, uma síntese que com o mesmo movimento seja e conheça, seja o que conhece, conheça o que é, conserve e suprime, realize e destrua. Se Hegel quer dizer que o passado, à medida que vai se afastando, transforma-se em seu sentido e que podemos retraçar posteriormente uma história inteligível do pensamento, tem razão, mas contanto que, nessa síntese, cada termo permaneça o todo do mundo na data considerada. Que ainda o encadeamento das filosofias as mantenha todas em seu lugar como outras tantas significações abertas e deixe subsistir entre elas uma troca de antecipações e de metamorfoses $^{48}$.

É mais precisamente este o ponto de partida que viria, aliás, se inflamar em Les Aventures de la Dialectique, no momento em que MerleauPonty problematiza acerca do que restará da dialética caso ela renuncie a ler a história buscando decifrar nesta uma espécie de "devir-verdade". O que a experiência mostra é que a dialética é "um pensamento com vários centros e várias entradas" 49 . Ela se institui como um "pensamento que não constitui o todo, mas que se encontra nele situado" ${ }^{50}$, no sentido de uma "coesão global, primordial de um campo de experiência, onde cada

\footnotetext{
${ }^{47}$ MERLEAU-PONTY, M. Éloge de la philosophie, p. 50-51. "A história não tem sentido se o seu sentido for concebido como o de um rio que, sob a ação de causas todo-poderosas, corre para um oceano, no qual desaparece. Qualquer recurso à história universal corta o sentido do acontecimento, torna insignificante a história efetiva e é uma máscara do niilismo" (Idem, Op. cit., p. 54).

${ }^{48}$ MERLEAU-PONTY, M. Signes, p. 103.

${ }^{49}$ MERLEAU-PONTY, M. Les aventures de la dialectique, p. 274.

${ }^{50}$ MERLEAU-PONTY, M. Les aventures de la dialectique, p. 274.
} 
elemento abre para os outros" ${ }^{11}$. Uma vez aberta essa via, a dialética é o que permite a história tornar-se visível em segunda potência, a ponto de envolver-nos sem qualquer previsibilidade total em face dos acontecimentos, já que a ação pode escolher entre várias possibilidades. Se a dialética é movimento de abertura, logo, jamais se realiza num estado revolucionário ou numa síntese do saber absoluto. Nesse movimento, "não é a dialética que está caduca, mas, sim, a pretensão de terminá-la num fim da história ou numa revolução permanente; em um regime que, sendo a contestação de si próprio, não precise mais ser contestado de fora e que, em suma, não tenha mais um fora" 52 .

Para além de qualquer finalismo, a história se abre inteiramente pondo em xeque uma presumida necessidade lógica que a inscreveria. Assim, um importante elemento aí se insere nesse processo heurístico: o peso da contingência. Esta não se encontra na superfície do fenômeno histórico, mas se engrena profundamente em seu movimento mais próprio.

Merleau-Ponty atesta que a "história tem sentido, mas não é um puro desenvolvimento da ideia, já que ela constrói seu sentido no contato com a contingência" ${ }^{3}$. A contingência passa a ser nesse curso, a referência pela qual o evento histórico se compreende. Assim, sem haver síntese garantida ou necessidade objetiva, "a experiência dessa contingência" - atenta Hyppolite - "é uma experiência considerável de nosso tempo"54. Ela é a condição pela qual se desenham linhas de força, para além da alternativa do real e do ideal, razão pela qual, "parece, pois, que a história oferece menos problemas do que enigmas"55. O enigma é que "a história é um sistema que vai, por saltos e crises" 56 . Não se dirige tendo em vista um futuro edênico que a justificaria absolutamente. Trata-se, no fundo, de uma história da qual não conhecemos mais que fragmentos, lacunas, lúgubres perspectivas. Uma vez posta a nu a contingência do acontecimento, já não há "história transparente e sem espessura" 57. Essa

\footnotetext{
${ }^{51}$ MERLEAU-PONTY, M. Les aventures de la dialectique, p. 274.

${ }^{52}$ MERLEAU-PONTY, M. Les aventures de la dialectique, p. 276-277. Conforme Dastur, "é a noção de existência que exige o recurso à dialética [...] ora, a pretensão de encarnar a dialética num sujeito absoluto da história conduz também a anular a história" (DASTUR, F. Merleau-Ponty et Hegel, p. 37; 38).

${ }^{53}$ MERLEAU-PONTY, M. Les aventures de la dialectique, p. 25.

${ }^{54}$ HYPPOLITE, J. Figures de la pensée philosophique, p. 699.

${ }^{55}$ MERLEAU-PONTY, M. Humanisme et terreur, p. 114.

${ }^{56}$ MERLEAU-PONTY, M. Humanisme et terreur, p. 144.

${ }^{57}$ MERLEAU-PONTY, M. Humanisme et terreur, p. 99.
} 
experiência "nos obriga a duvidar de nossas evidências"58, já que só "há história se há uma lógica na contingência, uma razão na desrazão"59. Desse modo,

[...] a contingência do acontecimento humano não é mais um defeito na lógica da história: ela torna-se, a bem da verdade, sua condição [...]. Há aí uma racionalidade na contingência, uma lógica vivida, uma autoconstituição da qual nós temos precisamente necessidade para compreender, em história, a união da contingência e do sentido ${ }^{60}$.

Merleau-Ponty quer denunciar "o artifício pelo qual a filosofia introduz o sistema na história, para depois o encontrar lá e reafirmar a sua onipotência quando parecia renunciar a ela"61. O que a lógica da contingência desvela é mais sutil: é o ardil de que a própria história é indeterminada, inacabada, mantendo, em si mesma, um "desequilíbrio criador":

Nesse caso, a história não seria mais um discurso com uma sequência determinada e cujo acabamento pode ser esperado com segurança. Não mais um discurso onde cada frase tem seu lugar necessário, mas, como palavras de um bêbado, discurso que indicaria uma ideia que logo se apagaria para reaparecer em seguida e voltar a desaparecer ainda uma vez, sem chegar necessariamente à sua expressão plena ${ }^{62}$.

Eis, então, a lição da história: "comporta vetores, tem um sentido; não que nela as coisas se disponham em vista de um fim, mas porque expulsa os homens e as instituições que não respondem aos problemas existentes" ${ }^{63}$. Contingente, ela fulgura um domínio de indeterminação pondo a prova "de que não há destino e que a existência do homem é aberta" 64 . O fato é que a "lógica e a história se divorciam de sorte que a história empírica nunca realiza aquilo que nos parece ser a sequência da lógica da história" ${ }^{65}$. Nada garante, aliás, que, no futuro, não haja incidentes, contragolpes imprevisíveis. Tudo se passa como se "houvesse na história uma espécie de malefício: ela solicita os homens, tenta-os. Eles crêem marchar no sentido aonde ela vai e, de súbito, ela se furta. $\mathrm{O}$ acontecimento muda, demonstra com fatos que outra coisa

\footnotetext{
${ }^{58}$ MERLEAU-PONTY, M. Humanisme et terreur, p. 113.

${ }^{59}$ MERLEAU-PONTY, M. Résumés de cours, p. 46.

${ }^{60}$ MERLEAU-PONTY, M. Éloge de la philosophie, p. 54; 56.

${ }^{61}$ MERLEAU-PONTY, M. Éloge de la philosophie, p. 52.

${ }^{62}$ MERLEAU-PONTY, M. Sens et non-sens, p. 147.

${ }^{63}$ MERLEAU-PONTY, M. Sens et non-sens, p. 128.

${ }^{64}$ MERLEAU-PONTY, M. Sens et non-sens, p. 144.

${ }^{65}$ MERLEAU-PONTY, M. Sens et non-sens, p. 146.
} 
era possível"66. Nesse percurso, "se abandonarmos resolutamente a ideia teológica de um fundo racional do mundo, a lógica da história torna-se apenas uma possibilidade entre outras"67.

Em meio a esse contexto, a "racionalidade passa do conceito para o coração da práxis inter-humana de tal maneira que certos fatos históricos assumem uma significação metafísica, de modo que a filosofia viva neles" ${ }^{68}$. O que a dialética revela é um valor heurístico do acontecimento: não se pode avaliar o sentido da história tendo como critério o verdadeiro e o falso. É que a história é vivenciada no fluxo de um devir que se corrige indefinidamente por outras vivências, já que está em vias de realização. Como retratara Marx, existe "uma relação interna entre o positivo e o negativo embora ele errasse ao restringi-la à dicotomia sujeito-objeto. Se a história chega a conter qualquer 'erro', esse 'erro' aqui não é o mero contrário da verdade, é antes uma verdade malograda"69, a partir da qual, convida-nos a falar para além dos enunciados e das proposições, se queremos ir mais longe. Em suma, se

[...] a história nos envolve a todos, cabe a nós compreender que o que podemos ter de verdade não se obtém contra a inerência histórica, mas, sim, por seu intermédio. Superficialmente pensada, a história destrói qualquer verdade; pensada radicalmente, funda uma nova ideia de verdade. Enquanto conservo em meu íntimo o ideal de um espectador absoluto, de um conhecimento sem ponto de vista, não posso ver em minha situação senão um princípio de erro ${ }^{70}$.

Merleau-Ponty quer pensar a dialética em sua mais radical historicidade, isto é, em sua verdade situacional, para além de qualquer $\tau \varepsilon ́ \lambda$ os necessário ou coerência interna que indicaria um sentido fixo e único. Tal qual uma tela de Cézanne, a história é como uma obra inacabada, permitindo captar, somente, instantes, flashes do mundo. Misteriosa, ela não se revela totalmente à razão. Ela se orienta, via uma lógica implacável: sua estrutura tensional. É que a dialética não é uma "relação entre pensamentos contraditórios e inseparáveis. É, antes, a tensão de uma existência em direção a outra existência que a nega e

\footnotetext{
${ }^{66}$ MERLEAU-PONTY, M. Humanisme et terreur, p. 71.

${ }^{67}$ MERLEAU-PONTY, M. Sens et non-sens, p. 147.

${ }^{68}$ MERLEAU-PONTY, M. Éloge de la philosophie, p. 53. O que a experiência ensina é que a "vida pessoal, a expressão, o conhecimento e a história avançam obliquamente, e não em linha reta para os fins ou para os conceitos" (Idem, Signes, p. 104). Logo, a filosofia não pode bastar-se a si mesma, isto é, que comece e se conclua com a apreensão do conceito (Idem, Op. cit., p. 180).

${ }^{69}$ MERLEAU-PONTY, M. Signes, p. 16. É que "a verdade não pode se fechar ou se instalar numa proposição fixa" (CUEILLE, J-N. La profondeur du négatif, p. 307).

${ }^{70}$ MERLEAU-PONTY, M. Signes, p. 137.
} 
sem a qual, todavia, ela não se sustenta"71. A tensão aparece como um princípio regente da existência, ou seja, a lógica mais secreta que anima a dialética como um elemento indispensável de sua compreensão. Daí outro traço tensional da dialética: a ambiguidade.

\section{5}

A correlação entre dialética e ambiguidade já pode ser entrevista desde La Structure du Comportement:

A dialética humana é ambígua: manifesta-se primeiro pelas estruturas sociais ou culturais que faz aparecer e nas quais se aprisiona. Os seus objetos de uso e os seus objetos culturais não seriam, todavia, o que são se a atividade que os faz aparecer não tivesse também por sentido negá-los e ultrapassá-los ${ }^{72}$.

Anos mais tarde, Merleau-Ponty precisa:

A dialética ou a sua ambiguidade é apenas uma maneira de por em palavras aquilo que todo homem sabe muito bem: o valor dos momentos nos quais sua vida se renova continuando-se, se retoma e se compreende, passando além, ali onde seu mundo privado torna-se mundo comum $^{73}$.

O argumento pressuposto nessas passagens é o princípio de que a existência é ambígua. Do mesmo modo, "o mundo em que vivemos é, a esse respeito, ambíguo [...] e jamais um mundo homogêneo, exposto, plano, sem profundeza nem interior" 74 . Trata-se, do "mundo humano como um sistema aberto ou inacabado"75, manifesto, em sua ambiguidade mais visceral, pela qual a existência histórica se efetiva dialeticamente. $O$ ambíguo é o "equívoco perpétuo" que perfaz o caráter alusivo, indireto, oblíquo do acontecimento. Ele pressupõe, na dialética, o sentido de uma indeterminação constitutiva.

\footnotetext{
${ }^{71}$ MERLEAU-PONTY, M. Phénoménologie de la perception, p. 195.

${ }^{72}$ MERLEAU-PONTY, M. La structure du comportement, p. 110.

${ }^{73}$ MERLEAU-PONTY, M. Éloge de la philosophie, p. 63.

${ }^{74}$ MERLEAU-PONTY, M. Humanisme et terreur, p. 161; 170.

${ }^{75}$ MERLEAU-PONTY, M. Humanisme et terreur, p. 193. "Não somos, justamente, espectadores de uma história acabada, somos atores em uma história aberta. Nossa práxis reserva a parte do que não é para se conhecer, mas para fazer. Ela é um ingrediente do mundo e é por isso que o mundo não é somente para ser contemplado, mas, antes, para ser transformado. É a hipótese de uma consciência sem futuro e de um fim da história que é para nós irrepresentável. Sempre, pois, enquanto houver homens, o futuro será aberto, não haverá o relativo (concernant) senão das conjecturas metódicas e não um saber absoluto" (Idem, Op. cit., p. 112).
} 
Nessa direção, acena Merleau-Ponty, não há outro caminho a ser perseguido senão o de abrir uma "terceira concepção de dialética", ou seja, o de instituir uma "filosofia da ambiguidade ou da percepção"76, capaz de fulgurar o espetáculo da diferença e do contraditório ${ }^{77}$. É que a dialética "é doravante ilegível, sendo pura transformação do contrário em contrário"78. Nesse sentido, "a dialética do subjetivo e do objetivo não é uma simples contradição que deixa separados os dois extremos entre os quais ela joga; ela testemunha, antes, nosso enraizamento na verdade"79. É assim que, no curso preparatório entre 1960 e 1961, "Philosophie et NonPhilosophie depuis Hegel", Merleau-Ponty reabre o debate, atentando para a relação entre a dialética e sua lógica congênita, a ambiguidade: "A ambiguidade", nota ele, "é essencial à dialética e à Experiência (Erfahrung), pois é por ela que o objeto passa no sujeito e vice-versa. Não há imanência; há, em sentido verdadeiro, aprendizagem. A Experiência se torna a solução do dilema: ou se sabe ou não se sabe" ${ }^{80}$. A "dialética assim compreendida é Experiência (Erfahrung), isto é, relação ao ser que é pré-objetivo, relação a um ser no qual nós somos tomados, pensados (begriffen)" 81 . Nesse cenário, "a ambiguidade não é falta de univocidade. Ela é 'boa' [...]. O que se tem, na verdade, é experiência do saber, saber da experiência: as duas faces da ambiguidade" 82 . Há, portanto, dois sentidos em que se pode tomar a ambiguidade: um "mal" e um "bom". A má ambiguidade é aquela que provém de um pensamento de sobrevoo, isto é, um pensar exaustivo como posse "em pensamento" da coisa, sem maior envolvimento entre o particular e o universal. A boa ambiguidade, ao contrário, almeja ambos: ela se exprime como um novo gesto reflexivo buscando realizar o que tem faltado, tornando-se, de fato, uma filosofia, em sua verdade mais radical e concreta ${ }^{83}$.

A boa ambiguidade será aquela capaz de se integrar noutra dimensão: a de um movimento de abertura pelo qual o "ser" e o "nada" perfazem

\footnotetext{
${ }^{76}$ MERLEAU-PONTY, M. L' institution/La passivité, p. 258.

77 "Não estamos mais no universo dialético de Platão, mas, no universo fluente de Heráclito" (MERLEAU-PONTY, M. Humanisme et terreur, p. 156). Como em Heráclito, trata-se de um processo que "não é nem a simples soma dos movimentos opostos nem um terceiro movimento acrescentado a eles, mas seu sentido comum, os dois movimentos componentes visíveis como um único movimento, como totalidade, isto é, espetáculo" (Idem, Le visible et l'invisible, p. 125).

${ }^{78}$ MERLEAU-PONTY, M. Humanisme et terreur, p. 154.

${ }^{79}$ MERLEAU-PONTY, M. Humanisme et terreur, p. 115.

${ }^{80}$ MERLEAU-PONTY, M. Notes de cours (1959-1961), p. 301. Se, até mesmo para Kant, a dialética é a arte da ilusão, para Hegel, a experiência é ela mesma uma dialética de modo que a raíz da dialética é a experiência (Cf. HYPPOLITE, J. Figures de la pensée philosophique, p. 209-210).

${ }^{81}$ MERLEAU-PONTY, M. Notes de cours (1959-1961), p. 305.

${ }^{82}$ MERLEAU-PONTY, M. Notes de cours (1959-1961), p. 319.

${ }^{83}$ Cf. MERLEAU-PONTY, M. Notes de cours (1959-1961), p. 340-341.
} 
o "avesso" e o "direito" um do outro ${ }^{84}$. Trata-se de uma abertura que desloca a filosofia de um plano absoluto, restrita apenas a uma espécie de pensamento "de dentro" e "de fora" clarividente, por princípio. A partir desse deslocamento, a filosofia assume outra expressão: ela se torna um pensamento dialético que "engloba tanto nossas negações como nossas afirmações" 85 . Ora, é rumo a essa terceira via que melhor se vislumbra a dimensão "hiper" com a qual Merleau-Ponty incorpora à noção de dialética. Esta se redefine não como uma "síntese de contrários", mas, como "hiperdialética", ou seja, uma ultrapassagem sem síntese. Nessa extensão, o sentido duplo da ambiguidade nada mais é do que o da própria dialética:

A má dialética quase começa com a dialética, só é boa dialética aquela que se critica a si mesma e se ultrapassa como enunciado separado; a boa dialética é hiperdialética. A má dialética é a que não quer perder sua alma para salvá-la, que quer ser dialética imediatamente, tornando-se autônoma e terminando no cinismo, no formalismo, por ter evitado seu próprio duplo sentido. $O$ que chamamos hiperdialética é um pensamento que, ao contrário, é capaz de verdade, pois encara sem restrição a pluralidade das relações e o que chamamos ambiguidade. A má dialética é a que acredita recompor o ser por um pensamento tético, mediante um conjunto de enunciados com tese, antítese e síntese. A boa dialética é aquela que é consciente de que toda tese é idealização, de que o Ser não é feito de idealizações ou de coisas ditas, conforme acredita a velha lógica, mas de conjuntos ligados em que a significação aparece apenas enquanto tendência em que a inércia do conteúdo nunca permite definir um termo como positivo e outro termo como negativo e ainda menos um terceiro termo como supressão absoluta dele e por ele mesmo. O ponto notável é esse aqui: que a dialética sem síntese de que falamos não é o ceticismo, o relativismo vulgar ou o reino do inefável. O que rejeitamos ou negamos não é a ideia de superação que reúne, é a ideia de que ela redunde num novo positivo, numa nova posição [...]. Em outros termos, o que excluímos da dialética é a ideia do negativo puro; o que buscamos é uma definição dialética do ser que não pode ser nem o ser para si nem o ser em $\mathrm{si}^{86}$.

\footnotetext{
${ }^{84}$ Ao debater o estatuto da dialética, Merleau-Ponty tem em foco, nesse momento, a ontologia sartriana do negativo. Ora, ao definir o ser e o nada como duas propriedades abstratas, Sartre fixa uma oposição maciça entre o Para Si e o Em Si. Trata-se de um pensamento totalizante, em que a subjetividade, mesmo que "soterrada no mundo", permanece, surpreendentemente, "estranha a ele". Por isso, "é pela abertura que poderemos compreender o ser e o nada e não pelo ser e o nada que compreenderemos a abertura" (MERLEAU-PONTY, M. Le visible et l'invisible, p. 135).

${ }^{85}$ MERLEAU-PONTY, M. Le visible et l'invisible, p. 109.

${ }^{86}$ MERLEAU-PONTY, M. Le visible et l'invisible, p. 129; 130.
} 
Essa longa passagem é especialmente significativa. Merleau-Ponty chama a atenção de que a "boa dialética" ou "hiperdialética" é aquela que assume uma atitude "autocrítica". Ela está para além de todo pensamento tético, positivo, se instituindo como um movimento "instável, no sentido que os químicos dão à palavra"87. Por isso:

Uma das tarefas da dialética, como pensamento de situação, pensamento em contato com o ser, é o de sacudir as falsas evidências, de denunciar as significações cortadas da experiência do ser, esvaziadas, e criticar-se a si mesma na medida em que se venha a tornar uma delas. Ora, ela é esse perigo que se corre desde que se enuncia em teses, em significações unívocas, desde que se separe de seu contexto ante-predicativo. E lhe essencial ser autocrítica ${ }^{88}$.

Afinal, qual o alcance dessa autocrítica? Merleau-Ponty adverte acerca de um iminente risco que ronda a dialética a tal ponto desta se "embalsamar" 89 ou de se tornar completamente desfigurada (brisée): o seu reducionismo tético. O que conjura a sua "derrota" é sua ambição de tornar-se um saber de evidência inscrito na "esfera de uma positividade perfeitamente segura"90. Ora, "não há visão positiva que me dê definitivamente a essencialidade da essência" ${ }^{1}$. A filosofia não visa puramente essências; ela deve ser, antes, capaz de interrogar "nossa abertura, nossa relação fundamental com o Ser"92. Por isso, mais que enunciar teses ou fixar um sentido unívoco aquém da experiência, a dialética não pode abster-se de ser autocrítica, ou seja, de interrogar a dimensão ambígua da vida, do mundo, da história. O que está em curso é outro movimento de reflexão, para além de toda idealização ou síntese.

Merleau-Ponty passa trabalhar a dialética como "coesão dos opostos". É preciso revogar a ontologia da identidade que reduz o real a um jogo entre o positivo e o negativo. Se o negativo deve liberar-se à "ditadura do positivo"93, é porque trata-se, agora, de reconhecer a verdadeira função do negativo. Por isso, a boa dialética será aquela na qual "o ser admite o negativo nele mesmo" 94 de modo que "cada termo só é

\footnotetext{
${ }^{87}$ MERLEAU-PONTY, M. Le visible et l'invisible, p. 126. "Merleau-Ponty busca empreender uma filosofia dialética, mas ele quer assinalar que essa aqui não foi jamais realizada completamente na história da filosofia em razão de sua instabilidade permanente" (CUEILLE, J-N. La profondeur du négatif, p. 327).

${ }^{88}$ MERLEAU-PONTY, M. Le visible et l'invisible, p. 126.

${ }^{89}$ MERLEAU-PONTY, M. Le visible et l'invisible, p. 96.

${ }^{90}$ MERLEAU-PONTY, M. Le visible et l'invisible, p. 98.

${ }^{91}$ MERLEAU-PONTY, M. Le visible et l'invisible, p. 111.

${ }^{92}$ MERLEAU-PONTY, M. Le visible et l'invisible, p. 125.

${ }^{93}$ MERLEAU-PONTY, M. Les aventures de la dialectique, p. 121.

${ }^{94} \mathrm{MERLEAU-PONTY,} \mathrm{M.} \mathrm{Inédits,} \mathrm{p.} 16$.
} 
ele próprio voltando-se para o termo oposto [...], ou seja, cada termo é sua própria mediação enquanto exigência de um devir e até mesmo de uma autodestruição que produz o outro" 95 . Em meio a esse contexto, "a questão não é de modo algum saber se a dialética está 'nas coisas' ou 'nas consciências'. Ambas as atitudes são antidialéticas. O que é dialético, o único meio da dialética são 'as relações entre pessoas mediadas pelas coisas'"96.

Para além de todo "paralelismo dialético", trata-se de explorar um terreno comum em que tanto o Mesmo quanto o Outro possam se imbricar. Ora, observa o filósofo, "nossas teses não passam de uma formulação apenas esquemática"97, já que há um "dilaceramento da reflexão que sai de si querendo entrar em si"98. "A verdadeira filosofia consiste em compreender aquilo que faz com que o sair de si seja entrar em si e vice-versa" 99 . Nesse vaivém, "sair de si" e "entrar em si" deixam de ser posições logicamente fixas (termos de um raciocínio rígido e compacto) para dar lugar a uma abertura recíproca pela qual o em-si e o para-si, longe de se contradizerem, se apreendem mais intimamente. A dialética aí reencontra seu movimento ambíguo figurado na própria alteridade. Por meio desse movimento, o Eu não é um positivo lógico ${ }^{100}$; tampouco, Outrem é um negativo lógico. O princípio admitido não é o da contradição ou da negação absoluta, mas a ideia de uma "negaçãoreferência", comum a todos. De sua desfiguração, a dialética reconstitui o seu verdadeiro rosto ao exprimir o intercâmbio entre o em si e o para si, hesitando, como diz Platão, "em dizer seu próprio nome, já que não sacrifica nada, pois quer sempre os dois"101.

É essa verdade de princípio, para além da identidade pura dos opostos, que comanda a lógica da terceira concepção de dialética em curso. Seu caráter "hiper" metaforiza o movimento de "ir além", de "transcender" toda polaridade rígida, positiva, indiferente ao sentido ambíguo da experiência. A boa dialética é aquela que desvela um Ser ambíguo e, ao mesmo tempo, transcendente ${ }^{102}$; que aprofunda, portanto,

\footnotetext{
${ }^{95}$ MERLEAU-PONTY, M. Le visible et l'invisible, p. 124.

${ }^{96}$ MERLEAU-PONTY, M. Inédits, p. 15.

${ }^{97}$ MERLEAU-PONTY, M. Signes, p. 104.

${ }^{98}$ MERLEAU-PONTY, M. Le visible et l'invisible, p. 173

${ }^{99}$ MERLEAU-PONTY, M. Le visible et l'invisible, p. 188; cf. também p. 56.

${ }^{100}$ MERLEAU-PONTY, M. Le visible et l'invisible, p. 189.

${ }^{101}$ MERLEAU-PONTY, M. Sens et non-sens, p. 163-164. Como mostra Hyppolite, "a Fenomenologia de Hegel justificara, nessa dialética da experiência, o sentido mais primitivo da palavra dialética, isto é, aquele do diálogo. O diálogo da alma com ela-mesma, aquele do qual fala Platão, em que o diálogo passa através das almas entre si" (HYPPOLITE, J. Figures de la pensée philosophique, p. 212).

${ }^{102}$ MERLEAU-PONTY, M. Le visible et l'invisible, p. 267.
} 
a "transcendência como a identidade na diferença"103. Eis então o seu signo: interrogar um "Ser que não é positividade simples, Em $\mathrm{Si}$, e que não é o Ser-posto de um pensamento, mas manifestação de Si, desvendamento, em vias de se fazer" ${ }^{104}$. A dialética adota outra atitude: ela se torna abertura, o próprio gesto palpável de "nossa implicação no Ser"105. Afinal, "não atingimos o universal abandonando a nossa particularidade, mas fazendo dela um meio para alcançar os outros, em virtude de uma afinidade misteriosa que faz com que as situações se compreendam entre si" ${ }^{106}$.

O que, enfim, é notável a despeito dessas formulações são as diferentes perspectivas com as quais a figura de Hegel é reconstituída sob a lente de Merleau-Ponty. E isso, seja no cenário da Fenomenologia do Espírito em que todo o cuidado com o sistema parece esquecido, seja naquele da Enciclopédia em que as oposições da história se superam mediante uma síntese superior. De um lado, há um Hegel adstrito, ainda, a um "racionalismo dogmático que elimina por antecipação a contingência histórica supondo-se como um 'Espírito do mundo' atrás do curso das coisas" ${ }^{107}$. Por outro, um Hegel mais afeto à ambiguidade no desdobramento do movimento dialético de modo que, sob esse plano, não estamos mais diante de um pensamento dogmático, mas de um projeto militante, concreto, um pensamento da contradição misturada à lógica da vida. Ora, este "racionalismo hegeliano", como bem nota Cueille, "não tem nada de comum com um racionalismo dogmático porque o absoluto que ele desvela se expõe negativamente no movimento conjunto do aparecer e do desaparecer" ${ }^{108}$. Nessa direção, "sua negatividade é sua positividade, aquela não pode jamais se manter como síntese final. Por colocar o trabalho do negativo no coração de seu pensamento, Hegel abre, pois, a filosofia a uma compreensão da contradição" ${ }^{109}$. Tudo se passa, postula Cueille, como se "Hegel nos convidasse ele-mesmo a prolongar a sua dialética e a contradizer o seu sistema"110.

Ao tomar este curso, Hegel nos deixa uma lição: a de que não se pode perder de vista as relações efetivas, ou seja, de ignorar a variedade das situações históricas, deixando escapar o sentido do concreto para além da disjunção entre o interior e o exterior. Esse legado não permanece intacto. Ele se encarna e se prolonga, intrepidamente, em nosso tempo; inspira

\footnotetext{
${ }^{103}$ MERLEAU-PONTY, M. Le visible et l'invisible, p. 207.

${ }^{104}$ MERLEAU-PONTY, M. Le visible et l'invisible, p. 125.

${ }^{105}$ MERLEAU-PONTY, M. Le visible et l'invisible, p. 117.

${ }^{106}$ MERLEAU-PONTY, M. Sens et non-sens, p. 113.

${ }^{107}$ MERLEAU-PONTY, M. Parcours deux (1951-1961), p. 46-47.

${ }^{108}$ CUEILLE, J-N. La profondeur du négatif, p. 316.

${ }^{109}$ CUEILLE, J-N. La profondeur du négatif, p. 303.

${ }^{110}$ CUEILLE, J-N. La profondeur du négatif, p. 326.
} 
a nossa ação e a história quando, para além do sistema, dá a conhecer, subterraneamente, uma práxis a-sistemática como verdadeiro motor da dialética. Reconhece-se, então, que o universal jamais prescinde do particular; a essência jamais se separa do fato. É sob esse ângulo que se pode melhor medir o alcance de uma filosofia concreta e militante que já estava a caminho: aquela do trabalho, da dor e da paciência do negativo que Hegel teria entrevisto em sua teoria dialética.

\section{Referências}

BAVARESCO, A.; COSTA, A. O. "Movimento lógico da figura hegeliana do senhor e do servo". In: Trans/Form/Ação, Marília, 36, 1 (jan.-abr. 2013), p. 37-60.

BENOIT, A. H. R. "A dialética hegeliana como superação da dialética platônica". In: Revista Idéias, IFCH-Unicamp, 1 (1995), p. 79-93.

BERGSON, H. La pensée et le mouvant: essais et conférences. Paris: PUF, 1969.

CUEILLE, J-N. "La profondeur du négatif: Merleau-Ponty face à la dialectique de Hegel". In: Chiasmi International, from nature to ontology, 2 (2000), p. 301-335.

DASTUR, F. "Merleau-Ponty et Hegel: ontologie et dialectique". In: Chiasmi International, thinking without dualisms today, 11 (2009), p. 33-48.

HEGEL, G.W.F. Nürnberger und Heidelberger Schriften (1808-1817). Frankfurt am Main. Suhrkamp Taschenbuch Wissenschaft, 1986, (Werke 4).

. Wissenschaft der Logik (Bd II). Frankfurt am Main. Suhrkamp Taschenbuch Wissenschaft, 1990, (Werke 6).

. Enciclopédia das ciências filosóficas em compêndio (1830): I - A Ciência da Lógica. Trad. Paulo Menezes. São Paulo: Loyola, 1995.

. Fenomenologia do espírito. 4. ed. Trad. P. Meneses. Petrópolis (RJ): Vozes, 2007.

Filosofia do direito. 2. ed. Trad. Agemir Bavaresco et al. São Paulo/Recife/São Leopoldo: Loyola/Editora UNISINOS/UNICAP, 2010.

HYPPOLITE, J. Figures de la pensée philosophique (T. I e II). Paris: PUF, 1991.

HUSSERL, E. Ideen zu einer reinen phänomenologie und phänomenologischen philosophie. Den Haag: Martinus Nijhoff, 1976.

KESSELRING, T. "Reconstrução racional da dialética no sentido de Hegel". In: STEIN, E.; BONI, L. Dialética e liberdade. Petrópolis (RJ)/Porto Alegre: Vozes/Editora da UFRS, 1993, p. 556-587.

KOJÈVE, A. Introduction à la lecture de Hegel. Paris: Gallimard, 1947.

LEBRUN, G. O avesso da dialética: Hegel à luz de Nietzsche. Trad. Renato Janine Ribeiro. São Paulo: Companhia das Letras, 1988.

MARCEL, G. "Les conditions dialectiques de la philosophie de l'intuition". In: Revue de Métaphysique et de Morale, XX, 5 (1912), p. 638-652.

MERLEAU-PONTY, M. La structure du comportement. Paris: PUF, 1942.

. Phénoménologie de la perception. Paris: Gallimard, 1945. 
C. A. F. Silva - Merleau-Ponty e a herança hegeliana da dialética

. Éloge de la philosophie. Paris: Gallimard, 1953.

. Signes. Paris: Gallimard, 1960.

. Le visible et l'invisible. Paris: Gallimard, 1964.

. Les aventures de la dialectique. Paris: Gallimard, 1967.

Résumés de cours: Collège de France (1952-1960). Paris: Gallimard, 1968.

Humanisme et terreur. Paris: Gallimard, 1972.

Sens et non-sens. Paris: Gallimard, 1996.

Notes de cours (1959-1961). Paris: Gallimard, 1996.

Parcours deux (1951-1961). Lagrasse: Verdier, 2000.

L'institution/La passivité: notes de cours au Collége de France (1954-1955).

Paris: Belin, 2003.

. "Inédits". In: DUPOND, P. Vocabulário de Merleau-Ponty. São Paulo: Martins Fontes, 2010.

STANGUENNEC, A. "O dialético, a dialética, as dialéticas em Hegel". Trad. Agemir Bavaresco/Danilo V. C. Costa/Paulo R. Konzen. In: Revista Opinião Filosófica, 2, 1 (jan.-jun. 2011), p. 33-49.

TAGGART, J. E. M. "Do verdadeiro sentido da dialética de Hegel". Trad. Danilo V. C. R. M. Costa. In: Problemata Rev. Int. de Filosofia, 4, 1 (jan.-jun. 2013), p. 315-333.

TAMINIAUX, J. "Merleau-Ponty: de la dialectique à l'hyperdialectique". In: Tijdschrift voor Filosofie, 01 (mar. 1978), p. 34-55. Também em Recoupements. Bruxelles: Ousia, 1982.

VAZ, H. C. L. "Senhor e escravo: uma parábola da filosofia ocidental". In: Síntese Nova Fase, 21 (jan.-abr. 1981), p. 7-29.

WAHL, J. Le malheur de la conscience dans la philosophie de Hegel. 2. ed. Paris: PUF, 1951.

\section{Endereço postal:}

UNIOESTE - PPG-Filosofia

Rua da Faculdade, 645 - Jardim Santa Maria

85903-000 Toledo, PR, Brasil

Fone: (45) 33797127

Data de recebimento: 30/09/2012

Data de aceite: 26/05/2014 